\title{
2. STATISTICAL STUDY OF SEA-ICE VARIABILITY AT THE PLANNED LOCATIONS OF LEG 151 DRILLING SITES ${ }^{1}$
}

\author{
Peter Wadhams ${ }^{2}$ and Maria Pia Casarini²
}

\begin{abstract}
Leg 151 of the Ocean Drilling Program (ODP) was conducted in the Fram Strait during the summer of 1993. Eight sites, extending between the latitudes of $78^{\circ} 22^{\prime} \mathrm{N}$ and $81^{\circ} 06^{\prime} \mathrm{N}$, had been selected by ODP as desirable drill sites. Prior to the drilling season, the authors conducted a statistical study of 26 years of data from the United Kingdom's Meteorological Office ice charts to determine the likelihood of encountering ice-free conditions during the months of August and September at each of the sites. We examined 1897 charts covering July-October of 1966-1991; although charts are issued twice-weekly, they were compiled daily during 1969-1979 and the daily charts were archived so that a large data set was available. We recorded the ice concentration at each of the eight sites from each of the charts, using the results to derive the probability of a site remaining ice free for 2-12 consecutive days during August-September and determine the most favorable time of year for a site to remain ice free for at least 4 consecutive days.

We found that there was a significant amelioration of ice conditions in 1971, which continued through to 1990, so data from 1971 to 1990 were used in the final analysis. We found that three of the sites in southern Fram Strait were very favorable for drilling, one was favorable, two were unfavorable, and two were so difficult as to be probably unreachable by an unstrengthened vessel. The actual experiences of the JOIDES Resolution and the chartered icebreaker support ship Fennica during Leg 151 are reviewed; they corresponded well with the predictions of our analysis.
\end{abstract}

\section{INTRODUCTION}

During 1991 the Ocean Drilling Program (ODP) developed plans for drilling on the fringes of the Arctic Ocean and defined eight sites in the Greenland Sea north of $78^{\circ} \mathrm{N}$ where it wished to investigate accessibility by the unstrengthened drillship JOIDES Resolution. Table 1 gives the original positions of the sites, and Figure 1 shows their locations on a bathymetric chart. Sites YERM1-5 were located either on the Yermak Plateau or in deeper water in the northern part of the Fram Strait, whereas Sites FRAM 1A, 1B, and 2 were located farther south in the vicinity of the Hovgaard Ridge.

Both sets of locations are subject to sea-ice coverage for much of the year. This coverage is not wholly seasonal, as would be the case for sites farther south in the Greenland Sea, but can occur at any time of year. It is determined by variability in the location of the polar front that separates polar surface water emerging from the Arctic Basin from warmer Greenland Sea surface water, notably the water of the West Spitsbergen Current. Wadhams $(1981,1986)$, in reviews of ice conditions in the Greenland Sea, showed that the interannual variability of the Fram Strait ice extent in summer can be greater than the difference between summer and winter ice extent in a single year. The result of these excursions of the ice edge is that ice-free conditions are possible at any time of year (although they are more frequent during summer) and that they may extend from days to months in duration. The JOIDES Resolution requires between 2 and 12 days of ice-free conditions for dynamic positioning at a site and for drilling a hole.

ODP requested that we determine the probability of encountering ice-free conditions at each of these sites for durations of 2-12 days during the months of August and September. We extended the study

'Thiede, J., Myhre, A.M., Firth, J.V., Johnson, G.L., and Ruddiman, W.F. (Eds.), 1996. Proc. ODP, Sci. Results, 151: College Station, TX (Ocean Drilling Program)

${ }^{2}$ Scott Polar Research Institute, University of Cambridge, Cambridge CB2 IER, United Kingdom.pw11@cus.cam.ac.uk to July and October for three reasons: (1) the ice extent in Fram Strait is not strongly seasonally determined, so it is possible that drilling can be contemplated outside high summer; (2) it was thought possible that ice severity in late summer may be correlated with severity earlier in the season, so that conditions in July could be a guide to whether drilling may be attempted successfully in August or September of the same year; and (3) in considering runs of ice-free days beginning in late September, it is necessary to analyze data from October.

\section{TECHNIQUE}

Several national meteorological offices produce regular ice charts for all or part of the Arctic, showing ice limits and also ice concentration and type. Examples are the Navy-NOAA (National Oceanic and Atmospheric Administration) Joint Ice Center in Suitland, Maryland; Ice Central in Ottawa (Atmospheric Environment Service); and the Norwegian Meteorological Institute in Oslo. In most cases, however, the charts are produced weekly, which makes it difficult to assess short-term fluctuations in ice coverage at sites located near ice margins.

The British Meteorological Office at Bracknell has produced ice charts since 1966 for the Atlantic sector of the Arctic (Baffin Bay to northern Russia) at a scale of 10 million (initially 10.25 million)

Table 1. Locations of North Atlantic-Arctic Gateways drill sites.

\begin{tabular}{lll}
\hline Site & Latitude & Longitude \\
\hline YERM1 & $81^{\circ} 06^{\prime} \mathrm{N}$ & $7^{\circ} \mathrm{E}$ \\
YERM2 & $79^{\circ} 38^{\prime} \mathrm{N}$ & $5^{\circ} 35^{\prime} \mathrm{E}$ \\
YERM3 & $80^{\circ} 28^{\prime} \mathrm{N}$ & $8^{\circ} 13^{\prime} \mathrm{E}$ \\
YERM4 & $80^{\circ} 16 \mathrm{~N}$ & $6^{\circ} 38^{\prime} \mathrm{E}$ \\
YERM5 & $79^{\circ} 58^{\prime} \mathrm{N}$ & $1^{\circ} 42^{\prime} \mathrm{E}$ \\
FRAM1A & $78^{\circ} 36^{\prime} \mathrm{N}$ & $3^{\circ} \mathrm{E}$ \\
FRAM1B & $78^{\circ} 33^{\prime} \mathrm{N}$ & $5^{\circ} \mathrm{E}$ \\
FRAM2 & $78^{\circ} 22^{\prime} \mathrm{N}$ & $1^{\circ} 25^{\prime} \mathrm{E}$ \\
\hline
\end{tabular}




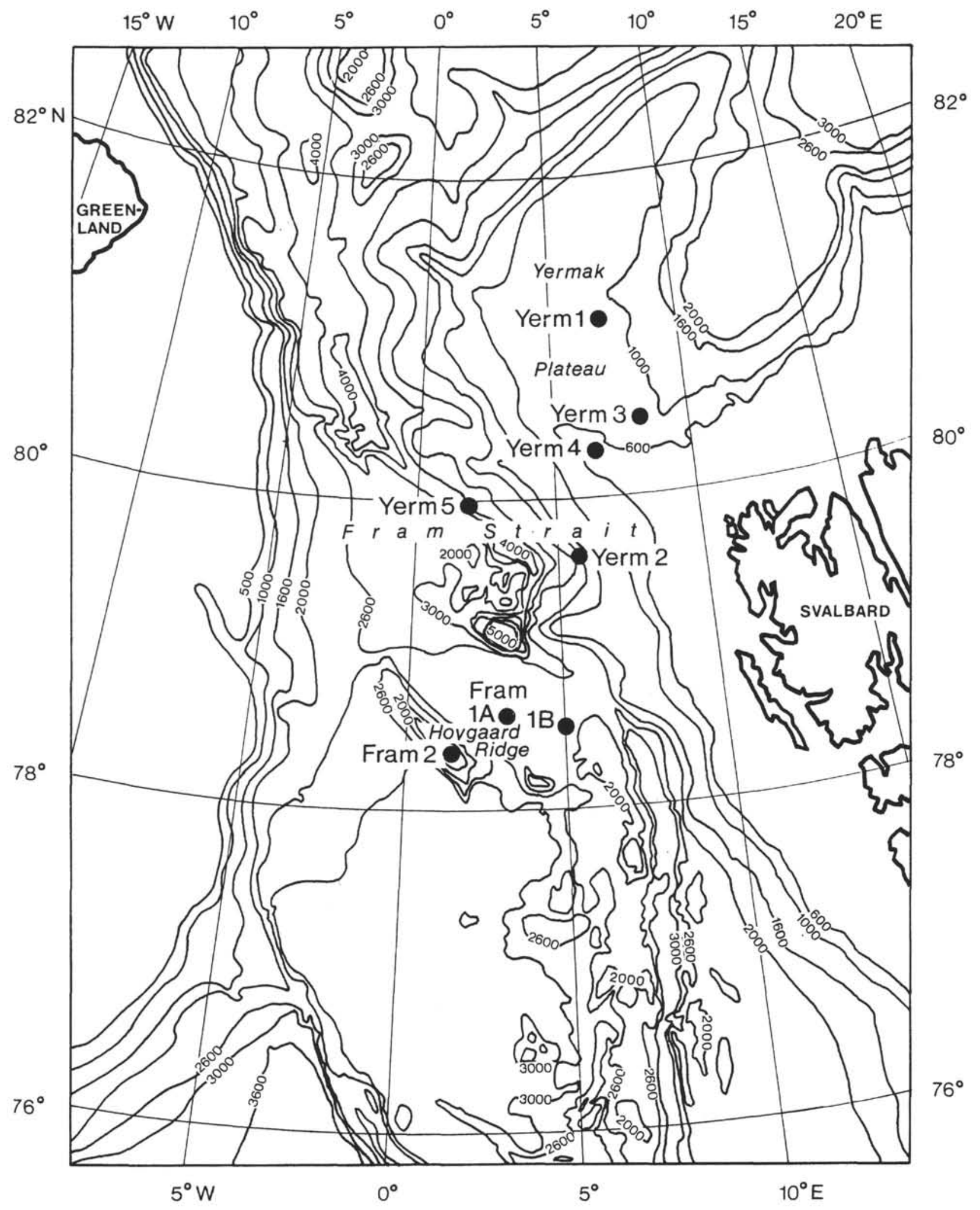

Figure 1. Location of drilling sites in the Fram Strait as originally proposed, with bathymetry (in meters). 
to 1 on a polar stereographic projection. The charts are generated from satellite imagery, aircraft, and ship reports. They show ice edge position and ice concentration in tenths within the ice edge, as well as indicating any special ice types present (new ice, heavy ridging, icebergs, etc.). They also show contours of sea surface temperature. Figure 2 shows a typical example of part of a chart, as originally drawn by hand. The style has changed slightly over the years but has remained consistent enough for the data set to be analyzed as a whole. In the early years, ship reports were frequent, and aircraft reconnaissance missions were shown, as well as reports from commercial airliners on polar routes. After about 1970, as satellite coverage improved, the charts became more dependent on satellite data alone. From 1973 onward, data from the NOAA series of satellites, using both visible and infrared frequencies (resolution $1.1 \mathrm{~km}$ ), have been combined with lower resolution $(20-30 \mathrm{~km})$, but weather-independent, data from the passive microwave sensors on the Nimbus- 5 and later Nimbus-7 spacecraft so that the quality of the chart inputs has remained quite consistent, and high, since that time.

The advantage of using Meteorological Office charts for our analysis is that they are currently issued twice weekly, which is an improvement over other nations' charts in the determination of shortduration changes in ice coverage. The Meteorological Office kindly made its archives available to us, and we were delighted to discover that charts were actually compiled daily from 1969 to 1979 . This allows statistics of ice-free periods to be generated down to the shortest interval requested by ODP ( 2 days). Table 2 gives a more complete description of how the chart production frequencies have changed over the years. It also shows how many charts we analyzed for each year. The overall total of charts examined is 1897 .

The analysis procedure was as follows. The eight site locations were carefully transferred onto a transparent plotting sheet of the correct scale and projection, and the sheet was laid over each chart. The ice conditions prevailing at each site were recorded. If ice covered the site, the fractional coverage was recorded; this was quoted as a range of tenths in early years (e.g., $7-9+/ 10,1-3 / 10$ ) but as a single value in later years. A separate symbol for "new ice" was also recorded. If the site was ice free, the surface water temperature at the site was recorded; this was done to show whether the site was clearly located in the warm (i.e., about $4^{\circ} \mathrm{C}$ ) surface water characteristic of the Greenland Sea, which would render it unlikely to be overwhelmed by ice by a single wind shift, or whether it was located in or close to polar surface water, implying that the ice edge had been caused to retreat by the wind or by warm air temperatures but could easily return to threaten the site.

When the site sat exactly on the borderline between two ice types, or between ice and open water, the two regimes were both recorded. "Exact" in this case means to within the resolution of the chart and the overlay, which we estimate to be $1 \mathrm{~km}$ at best. This value does not include error on the part of the chart compiler, who is assumed to have been perfect, or at least unbiased. In fact the accuracy with which the chart was compiled is itself limited by the resolution of the satellite data used.

\section{INTERPRETATION OF RESULTS Overall Probability of Ice-Free Conditions}

Our first task was to provide answers to two questions: (1) are August and September the best months to attempt drilling in Fram Strait, or should July and October be considered as alternatives, and (2) are there any significant trends in ice conditions during 1966-1991 that would render it necessary to use only a part of the data set for statistical analysis?

To examine these questions we looked at the overall statistics of ice-free conditions. Table 3 shows the number of ice-free days per month for each site for each year of the analysis. An "ice-free day" is defined as a day in which the site is situated in open water, not on a boundary between open water and any concentration of ice. The occasional occurrences of "new ice" and "new brash" are treated as open water, because these ice types represent only a day or two of in situ growth of very thin ice $(<10 \mathrm{~cm}$, detected by its passive microwave signature); such ice can be tolerated by even a completely unprotected vessel. Where ice charts were not produced daily, transition dates to and from ice-free conditions are estimated by interpolation between the relevant pair of charts. This implies that the statistics presented in Table 3 are unbiased, but they are exactly correct only for the period 1969-1979 where charts were produced daily.

The results for 1966-1990 are summed and presented in Table 4. The yearly totals for ice-free site-days for the Yermak and Fram Strait site groups are plotted in Figure 3. We can draw the following four conclusions from our results:

1. Ice conditions were significantly harsher than average during the period 1966-1970 (Fig. 3; few ice-free days), but they fluctuated around a fairly stable long-term running average from 1971 onward to 1990 . We may, therefore, take any reasonable run of years during the 1971-1990 period as being representative of the recent ice regime in the Fram Strait region.

2. August and September are clearly the most favorable months for ice at all eight sites, with August being favored at Y2, Y3, Y4, F1A, F1B, and F2, and September at Y1 and Y5.

3. At the Fram Strait (F) sites, ice conditions are favorable during all 4 months, with July and October not lagging significantly behind August and September. At these sites, therefore, drilling could take place earlier in the summer or later into autumn without a greatly increased probability of being affected by ice. This is not true of the Yermak (Y) sites, where July and October are significantly more unfavorable than high summer (Table 4).

4. The most difficult sites at which to drill are Y1 and Y5, where ice-free conditions occurred less than 1 day in 7 during the 4month, 25-year test period. Next come Y3 and Y4, where icefree conditions occurred 1 day in 3 . Better is site $\mathrm{Y} 2$, where ice-free conditions occurred two-thirds of the time. Best of all are the F sites, where ice-free conditions occurred at least $80 \%$ (and for F1A at least $90 \%$ ) of the time (Table 4).

\section{Probability of Ice-Free Conditions for a Specified Number of Days}

Information was required on the probability of a site remaining free of ice for periods of 2-12 days during the months of AugustSeptember. We were also required to find the most favorable time of year for a site to remain free of ice for at least 4 days.

The first question can be posed in two different ways:

1-1. If I spend the months of August and September in the Fram Strait area in an unstrengthened ship, what is the probability that during these 2 months I can find at least one period of from 2 to 12 days during which I can occupy the site in question?

1-2. If I sail toward the site in question in an unstrengthened ship during the months of August or September, what is the probability that I can reach the site immediately and remain there for a subsequent period of from 2 to 12 days?

Clearly, the answers to $1-1$ will show a higher success probability than those to 1-2.

To answer these questions, we chose the period from 1970 to 1979 from which to generate our statistics. During this time, ice charts were produced daily; therefore, we can validly estimate the probabil- 


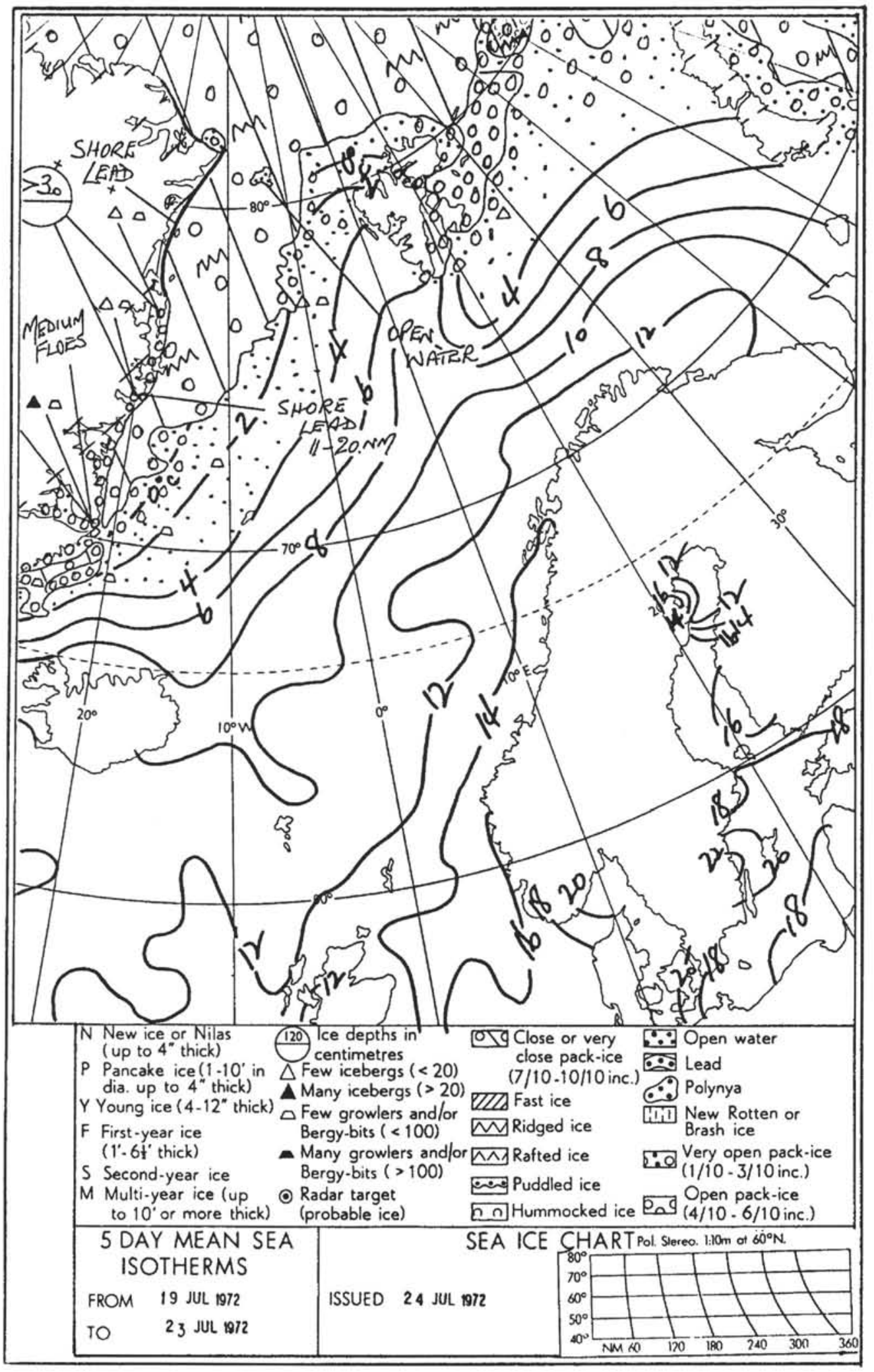

Figure 2. A typical section of a British Meteorological Office ice chart covering the Fram Strait, with original hand contouring. 
ities of ice-free periods of duration down to a day. For consistency, we must use the same data set to estimate the probabilities of ice-free periods of longer duration, rather than use data from years when chart production was more infrequent and when a brief period of ice cover could go undetected between successive charts showing ice-free conditions. As Figure 3 shows, the 10-year period 1970-1979 is very typical of ice conditions over the past 20 years, only 1970 being anomalously low. The running means of July-October ice-free sitedays for 1970-1979 and 1970-1990 compare very well:

\begin{tabular}{lccc}
\hline & $1966-90$ & $1970-79$ & $1970-90$ \\
\hline Yermak sites & 185 & 219 & 220 \\
All sites & 507 & 550 & 562 \\
\hline
\end{tabular}

Thus, we can state with confidence that the availability of daily ice charts from 1970 to 1979 allows us the opportunity to generate ice statistics that are applicable to the whole 1970-1990 period.

Table 5 shows the results of the analysis of the occurrence of consecutive ice-free days for August-September during the 1970-1979 period, whereas Table 6 shows these results averaged for the 10 years and expressed as a percent probability of encountering $N$ successive ice-free days if a given site is approached on a random day during August or September. Table 5 was generated by going through the original results and counting the number of days during each month when ice-free conditions occurred both on that day and on at least $(N-1)$ subsequent days. In this respect, the fact that the original analysis had been carried through into October permitted us to continue a valid analysis up to the end of September.

A comparison of Table 6 with Table 4 shows slight differences between the results for August and September. In some cases, for instance, the probability of encountering a 2-day ice-free period, according to Table 6 , is greater than the probability of encountering a single ice-free day according to Table 4 . This is simply because Table 6 is based on 1970-1979 data, which are representative of ice conditions during 1970-1990, whereas Table 4 is based on the entire 1966-1990 period, which includes some harsh ice years in the late 1960 s. Table 4 should therefore be taken as a pessimistic, or conservative, view of the occurrence of ice in the region.

Table 6 represents the answer to question 1-2. If a drilling ship approaches a proposed drill site on a random day, with no attempt to check the ice conditions beforehand, what is the historical probability that it will not only find open water but also find open water that will persist for a certain number of days? The results confirm the division that we have already made of drill sites into four classes. The FRAM sites (F1A, F1B, and F2) are very favorable, with probabilities between $82 \%$ and $99 \%$ of finding a 2-day ice-free period occurring at the site, and $76 \%$ to $95 \%$ probabilities of finding a 12-day period. Note how little decline in probability occurs as we extend the ice-free period; clearly these sites are ice free most of the time, so a long icefree interval is almost as likely as a short one. Site Y2 is the next most favorable site, with $72 \%$ (August) or $74 \%$ (September) probability of encountering a 2-day interval, but the probabilities sink more rapidly, to $53 \%$ (both months), as the interval is increased to 12 days. Sites Y3 and $\mathrm{Y} 4$ are relatively unfavorable, with $56 \%$ to $57 \%$ probability of a 2-day period in August and 38\% to $42 \%$ in September. These figures sink rapidly to $36 \%$ and $20 \%$ to $21 \%$, respectively, for 12 -day periods; it is a consistent feature of Table 6 that the lower the 2-day probability is, the lower the 12-day probability is as a fraction of it. Sites Y1 and Y5 are the worst, and we see that the probability of encountering the beginning of a 12-day ice-free interval at Site Y5 in August is only $1 \%$.
Table 2. British Meteorological Office ice chart frequencies, 1966-1991, and numbers of charts analyzed.

\begin{tabular}{lcl}
\hline & $\begin{array}{c}\text { No. charts } \\
\text { analyzed } \\
\text { July-October }\end{array}$ & \\
\hline 1966 & 19 & Approximately once per week \\
1967 & 18 & Approximately once per week \\
1968 & 87 & Daily except for Saturday and Sunday \\
1969 & 123 & Daily \\
1970 & 123 & Daily \\
1971 & 121 & Daily \\
1972 & 122 & Daily \\
1973 & 123 & Daily \\
1974 & 106 & Daily \\
1975 & 123 & Daily \\
1976 & 123 & Daily \\
1977 & 123 & Daily \\
1978 & 123 & Daily \\
1979 & 123 & Daily \\
1980 & 53 & Approximately 3 times per week \\
1981 & 53 & Approximately 3 times per week \\
1982 & 35 & Approximately twice weekly \\
1983 & 34 & Approximately twice weekly \\
1984 & 34 & Approximately twice weekly \\
1985 & 36 & Approximately twice weekly \\
1986 & 35 & Approximately twice weekly \\
1987 & 32 & Approximately twice weekly \\
1988 & 34 & Approximately twice weekly \\
1989 & 35 & Approximately twice weekly \\
1990 & 35 & Approximately twice weekly \\
1991 & 24 & Approximately twice weekly (to Sept 19) \\
\hline & & \\
\hline & &
\end{tabular}

Note: Total number of charts analyzed $=1897$.

To answer question 1-1, we must extract from the data in Table 5 the number of years during which at least one instance of an $\mathrm{N}$-day ice-free interval occurred during the months of August, September, and August-September together. The results are shown in Table 7. Here, the answers are necessarily crude, as we are quoting only numbers of years out of 10 . However, it is not statistically valid to use the whole 26-year data set for the long intervals but not for the short (which can be measured only for 1970-1979). The results are clearly more optimistic than they are in Table 6 , but we must remember that these probabilities imply the necessity of a drillship heaving-to outside the ice edge and waiting for a whole month or a whole 2 -month period for conditions to change; Table 7 then gives the likelihood (in tenths) that this change will occur. Again, we see a virtual certainty of appropriate conditions occurring for the FRAM sites, a high probability for Y2, a lower probability for Y3 and Y4, and the lowest probability for $\mathrm{Y} 1$ and $\mathrm{Y} 5$.

Finally, we answer question 2. During the whole period of August-September, which part of which month is the most favorable for a site to remain ice free for at least 4 days? We examined the whole data set for 1970-1979, once again because daily ice charts guarantee that a 4-day ice-free period is genuinely ice free, without ice intrusions as might be the case when the charts are only generated twiceweekly (i.e., at 4-day intervals). We noted the dates during August and September when an ice-free day was encountered that was followed by 3 other successive ice-free days and summed the results to yield the number of years out of 10 that this date was ice free in such a way. The results are plotted in Figure 4.

A 10 -year record inevitably produces a crude result, but there is a clear trend visible on most of the records. In Y2, Y3, and Y4, there is a definite tendency for ice-free conditions to be most prevalent in late August (August 18-20 for Y2, 19-21 for Y3, and 21 for Y4), with the probability falling away on either side of those dates. A similar trend is visible in Y5, although there are too few ice-free years to create a clear peak; the maximum probability occurs during August 14-17. Sites F1A, F1B, and F2 are ice free almost every year, so the curve is "saturated." Even so, there is evidence of a slightly greater tendency 
Table 3. Numbers of ice-free days per month at each site, 1966-1991.

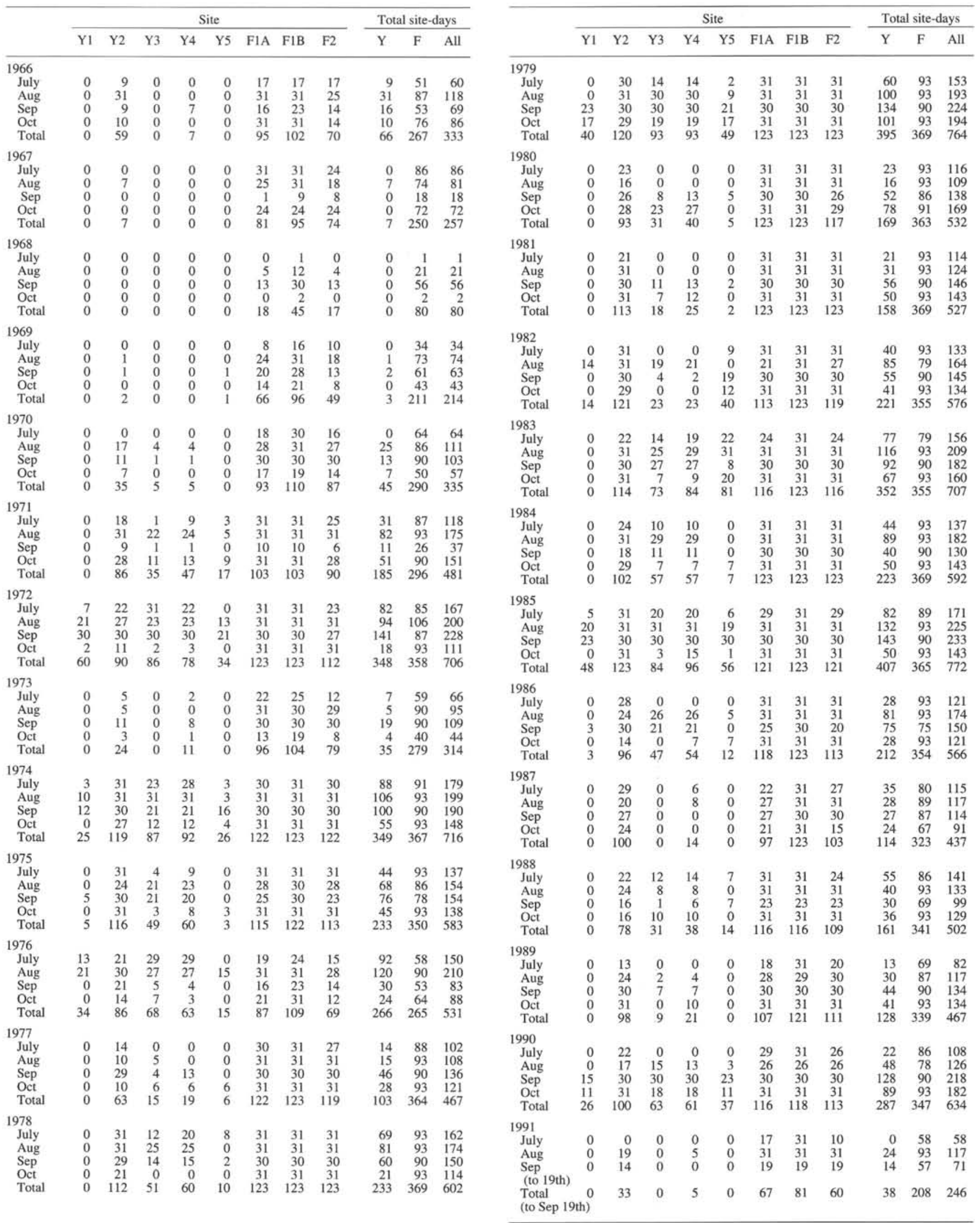


Table 4. Total ice-free site-days over the 25 summers from 1966 to 1990.

\begin{tabular}{|c|c|c|c|c|c|c|c|c|c|c|c|}
\hline & \multicolumn{8}{|c|}{ Site } & \multicolumn{3}{|c|}{ Totals } \\
\hline & $\mathrm{Y} 1$ & Y2 & Y3 & Y4 & Y5 & F1A & F1B & $\mathrm{F} 2$ & YERM & FRAM & All \\
\hline July & $\begin{array}{l}28 \\
(3.6)\end{array}$ & $\begin{array}{l}478 \\
(61.7)\end{array}$ & $\begin{array}{l}170 \\
(21.9)\end{array}$ & $\begin{array}{l}202 \\
(26.1)\end{array}$ & $\begin{array}{l}60 \\
(7.7)\end{array}$ & $\begin{array}{l}638 \\
(82.3)\end{array}$ & $\begin{array}{l}702 \\
(93.6)\end{array}$ & $\begin{array}{l}597 \\
(77.0)\end{array}$ & $\begin{array}{l}938 \\
(24.2)\end{array}$ & $\begin{array}{c}1,937 \\
(83.3)\end{array}$ & $\begin{array}{l}2,875 \\
(46.4)\end{array}$ \\
\hline Aug & $\begin{array}{l}86 \\
\text { (11.1) }\end{array}$ & $\begin{array}{l}556 \\
(71.7)\end{array}$ & $\begin{array}{l}343 \\
(44.3)\end{array}$ & $\begin{array}{l}356 \\
(45.9)\end{array}$ & $\begin{array}{l}103 \\
(13.3)\end{array}$ & $\begin{array}{l}708 \\
(91.4)\end{array}$ & $\begin{array}{l}747 \\
(96.4)\end{array}$ & $\begin{array}{l}694 \\
(89.5)\end{array}$ & $\begin{array}{r}1,444 \\
(37.3)\end{array}$ & $\begin{array}{l}2,149 \\
\quad(92.4)\end{array}$ & $\begin{array}{l}3,593 \\
\quad(58.0)\end{array}$ \\
\hline Sep & $\begin{array}{l}111 \\
(14.8)\end{array}$ & $\begin{array}{l}537 \\
(71.6)\end{array}$ & $\begin{array}{l}277 \\
(36.9)\end{array}$ & $\begin{array}{l}310 \\
(41.3)\end{array}$ & $\begin{array}{l}155 \\
(20.7)\end{array}$ & $\begin{array}{l}626 \\
(83.5)\end{array}$ & $\begin{array}{l}686 \\
(91.5)\end{array}$ & $\begin{array}{l}607 \\
(80.9)\end{array}$ & $\begin{array}{l}1,390 \\
(35.9)\end{array}$ & $\begin{array}{c}1,919 \\
(82.5)\end{array}$ & $\begin{array}{l}3,309 \\
(53.4)\end{array}$ \\
\hline Oct & $\begin{array}{l}30 \\
(3.9)\end{array}$ & $\begin{array}{l}486 \\
(62.7)\end{array}$ & $\begin{array}{l}135 \\
(17.4)\end{array}$ & $\begin{array}{l}180 \\
(23.2)\end{array}$ & $\begin{array}{l}97 \\
(12.5)\end{array}$ & $\begin{array}{l}668 \\
(86.2)\end{array}$ & $\begin{array}{l}705 \\
(91.0)\end{array}$ & $\begin{array}{l}617 \\
(79.6)\end{array}$ & $\begin{array}{l}928 \\
(23.9)\end{array}$ & $\begin{array}{c}1,990 \\
(85.6)\end{array}$ & $\begin{array}{l}2,918 \\
(47.1)\end{array}$ \\
\hline Total & $\begin{array}{l}255 \\
(8.3)\end{array}$ & $\begin{array}{r}2,057 \\
(66.9)\end{array}$ & $\begin{array}{l}925 \\
(30.1)\end{array}$ & $\begin{array}{c}1,048 \\
(34.1)\end{array}$ & $\begin{array}{l}415 \\
(13.5)\end{array}$ & $\begin{array}{r}2,640 \\
(85.9)\end{array}$ & $\begin{array}{r}2,840 \\
(92.4)\end{array}$ & $\begin{array}{r}2,515 \\
(81.8)\end{array}$ & $\begin{array}{l}4,700 \\
(30.3)\end{array}$ & $\begin{array}{c}7,995 \\
(86.0)\end{array}$ & $\begin{array}{r}12,695 \\
(51.2)\end{array}$ \\
\hline
\end{tabular}

Note: The numbers in parentheses are the likelihood (in percent) of encountering ice-free conditions on a given day of the given month at the given site.

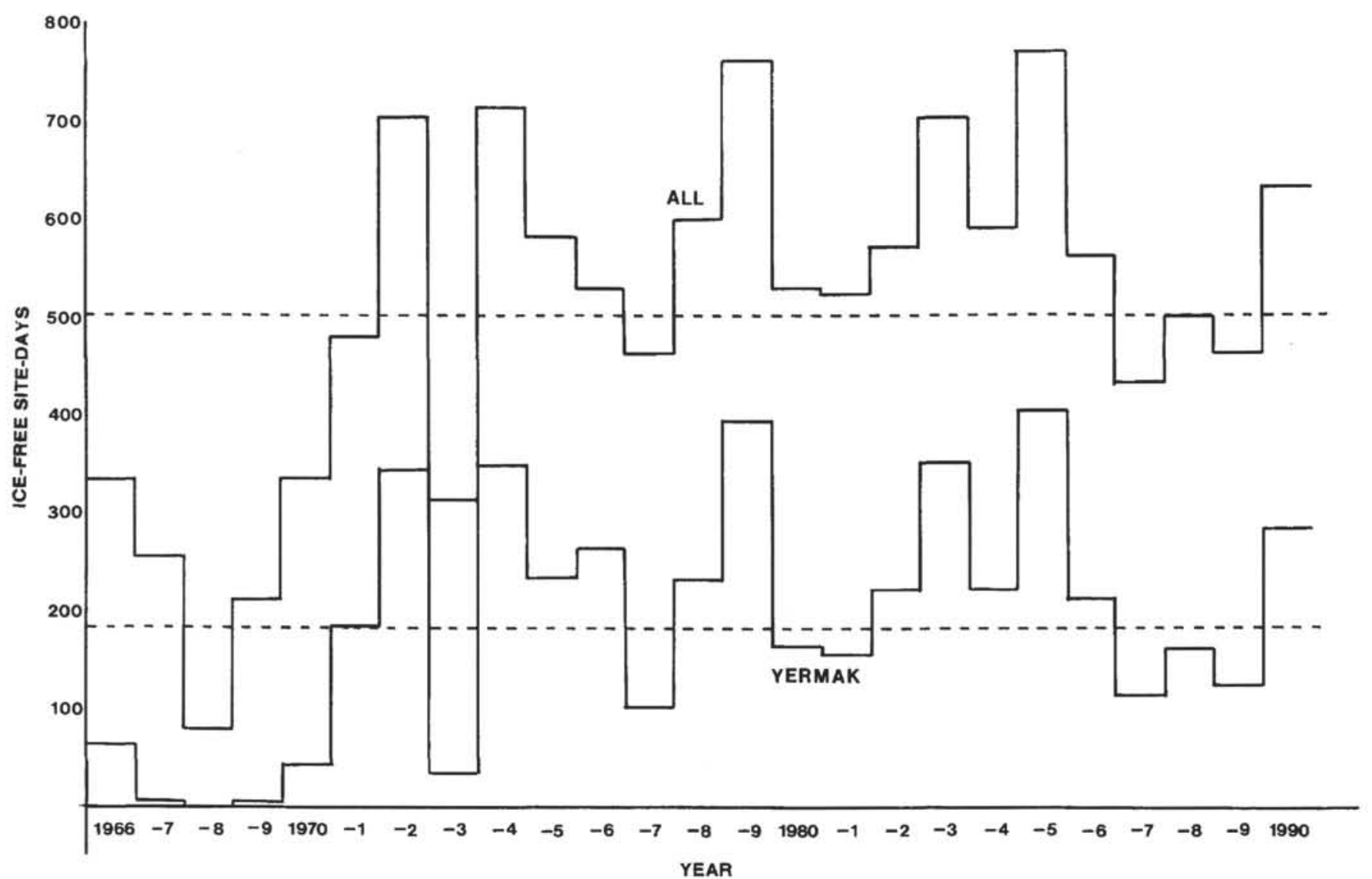

Figure 3. Total number of ice-free site-days during July-October for each year from 1966 to 1990 . The lower histogram shows YERM sites only; the upper shows YERM and FRAM together. Dashed line $=25$-year mean. 
Table 5. Occurrence of successive ice-free days (per month).

\begin{tabular}{|c|c|c|c|c|c|c|c|c|c|c|c|c|}
\hline & & & & & & $\mathrm{Nur}$ & ber 0 & lays & & & & \\
\hline & Site & 2 & 3 & 4 & 5 & 6 & 7 & 8 & 9 & 10 & 11 & 12 \\
\hline 1970 & & & & & & & & & & & & \\
\hline Aug & $\mathrm{Y} 1$ & & 0 & 0 & 0 & & & & 0 & 0 & 0 & 0 \\
\hline & $\mathrm{Y} 2$ & 14 & 11 & 10 & 8 & 6 & 4 & 2 & 1 & 0 & 0 & 0 \\
\hline & $\mathrm{Y} 3$ & 3 & 1 & 0 & 0 & 0 & 0 & 0 & 0 & 0 & 0 & 0 \\
\hline & Y4 & 3 & 1 & 0 & 0 & 0 & 0 & 0 & 0 & 0 & 0 & 0 \\
\hline & Y5 & 0 & 0 & 0 & 0 & 0 & 0 & 0 & 0 & 0 & 0 & 0 \\
\hline & FIA & 26 & 25 & 24 & 23 & 22 & 21 & 21 & 21 & 21 & 21 & 21 \\
\hline & F1B & 31 & 31 & 31 & 31 & 31 & 31 & 31 & 31 & 31 & 31 & 31 \\
\hline & $\mathrm{F} 2$ & 26 & 25 & 24 & 23 & 22 & 21 & 21 & 21 & 21 & 21 & 21 \\
\hline Sept & Y1 & 0 & 0 & 0 & 0 & 0 & 0 & 0 & 0 & 0 & 0 & 0 \\
\hline & $\mathrm{Y} 2$ & 8 & 5 & 2 & 1 & 0 & 0 & 0 & 0 & 0 & & 0 \\
\hline & Y3 & 0 & 0 & 0 & 0 & 0 & 0 & 0 & 0 & 0 & 0 & 0 \\
\hline & $\mathrm{Y} 4$ & 0 & 0 & 0 & 0 & 0 & 0 & 0 & 0 & 0 & 0 & 0 \\
\hline & Y5 & 0 & 0 & 0 & 0 & 0 & 0 & 0 & 0 & 0 & 0 & 0 \\
\hline & F1A & 30 & 30 & 30 & 30 & 30 & 30 & 30 & 30 & 30 & 30 & 30 \\
\hline & FIB & 30 & 30 & 30 & 30 & 30 & 30 & 30 & 30 & 30 & 30 & 30 \\
\hline & $\mathrm{F} 2$ & 30 & 30 & 30 & 30 & 30 & 30 & 30 & 30 & 30 & 30 & 30 \\
\hline 1971 & & & & & & & & & & & & \\
\hline Aug & Y1 & 0 & 0 & 0 & 0 & 0 & 0 & 0 & 0 & 0 & 0 & 0 \\
\hline & $\mathrm{Y} 2$ & 31 & 31 & 31 & 31 & 31 & 31 & 31 & 31 & 31 & 30 & 29 \\
\hline & Y3 & 18 & 17 & 16 & 15 & 14 & 13 & 12 & 11 & 10 & 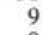 & 8 \\
\hline & $\mathrm{Y} 4$ & 22 & 20 & 18 & 16 & 14 & 13 & 12 & 11 & 10 & 9 & 8 \\
\hline & Y5 & 2 & 1 & 0 & 0 & 0 & 0 & 0 & 0 & 0 & 0 & 0 \\
\hline & F1A & 31 & 31 & 31 & 31 & 31 & 31 & 31 & 31 & 31 & 30 & 29 \\
\hline & FIB & 31 & 31 & 31 & 31 & 31 & 31 & 31 & 31 & 31 & 30 & 29 \\
\hline & $\mathrm{F} 2$ & 31 & 31 & 31 & 31 & 31 & 31 & 30 & 29 & 28 & 27 & 26 \\
\hline Sept & $\mathrm{Yl}$ & 0 & 0 & 0 & 0 & 0 & 0 & 0 & 0 & 0 & 0 & 0 \\
\hline & & 8 & 7 & 6 & 5 & 4 & 3 & 2 & 1 & 0 & 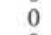 & 0 \\
\hline & $\mathrm{Y} 3$ & 0 & 0 & 0 & 0 & 0 & 0 & 0 & 0 & 0 & , & 0 \\
\hline & Y4 & 0 & 0 & 0 & 0 & 0 & 0 & 0 & 0 & 0 & 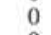 & 0 \\
\hline & Y5 & 0 & 0 & 0 & 0 & 0 & 0 & 0 & 0 & 0 & 0 & 0 \\
\hline & F1A & 9 & 8 & 7 & 6 & 5 & 4 & 3 & 2 & 1 & 1 & 1 \\
\hline & $\mathrm{F} 2$ & 9 & 8 & 7 & 6 & 5 & 4 & 3 & 2 & 1 & 1 & 1 \\
\hline & $\mathrm{F} 2$ & 5 & 4 & 3 & 2 & 1 & 0 & 0 & 0 & 0 & 0 & 0 \\
\hline
\end{tabular}

1972

$\begin{array}{lllllllllllll}\text { Aug } & \text { Y1 } & 21 & 21 & 21 & 21 & 21 & 21 & 21 & 21 & 21 & 21 & 21 \\ \text { Y2 } & 26 & 25 & 24 & 23 & 23 & 23 & 23 & 23 & 23 & 23 & 23\end{array}$ $\begin{array}{llllllllllll}\mathrm{Y} 2 & 26 & 25 & 24 & 23 & 23 & 23 & 23 & 23 & 23 & 23 & 23 \\ \mathrm{Y} 3 & 23 & 23 & 23 & 23 & 23 & 23 & 23 & 23 & 23 & 23 & 23\end{array}$

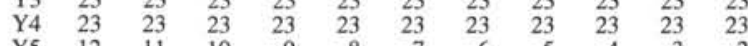

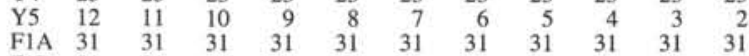

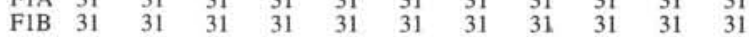
$\begin{array}{llllllllllll}\mathrm{F} 2 & 31 & 31 & 31 & 31 & 31 & 31 & 31 & 31 & 31 & 31 & 31\end{array}$

$\begin{array}{lllllllllllll}\text { Sept } & Y 1 & 30 & 30 & 29 & 28 & 27 & 26 & 25 & 24 & 23 & 22 & 21\end{array}$ $\begin{array}{llllllllrlll}\mathrm{Y} 2 & 30 & 30 & 30 & 29 & 28 & 27 & 26 & 5 & 24 & 23 & 22 \\ \mathrm{Y} 3 & 30 & 30 & 29 & 28 & 27 & 26 & 25 & 24 & 23 & 22 & 21\end{array}$ $\begin{array}{llllllllllll}\mathrm{Y} 3 & 30 & 30 & 29 & 28 & 27 & 26 & 25 & 24 & 23 & 22 & 21 \\ \mathrm{Y} 4 & 30 & 30 & 29 & 28 & 27 & 26 & 25 & 24 & 23 & 22 & 21 \\ \mathrm{Y} 5 & 19 & 17 & 15 & 13 & 11 & 9 & 7 & 6 & 5 & 4 & 3\end{array}$ $\begin{array}{llllllrrrrrr}\text { Y5 } & 19 & 17 & 15 & 13 & 11 & 9 & 7 & 6 & 5 & 4 & 3 \\ \text { F1A } & 30 & 30 & 30 & 30 & 30 & 30 & 30 & 30 & 30 & 30 & 30\end{array}$

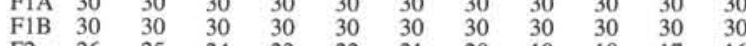
1973

$\begin{array}{llllllllllll}\text { Aug } \mathrm{Y} 1 & 0 & 0 & 0 & 0 & 0 & 0 & 0 & 0 & 0 & 0 & 0\end{array}$ $\begin{array}{llllllllllll}\text { Y1 } & 0 & 0 & 0 & 0 & 0 & 0 & 0 & 0 & 0 & 0 & 0 \\ \text { Y3 } & 2 & 1 & 0 & 0 & 0 & 0 & 0 & 0 & 0 & 0 & 0 \\ \text { Y } & 0 & 0 & 0 & 0 & 0 & 0 & 0 & 0 & 0 & 0 & 0\end{array}$ $\begin{array}{llllllllllll}\mathrm{Y} 4 & 0 & 0 & 0 & 0 & 0 & 0 & 0 & 0 & 0 & 0 & 0 \\ \mathrm{Y} 5 & 0 & 0 & 0 & 0 & 0 & 0 & 0 & 0 & 0 & 0 & 0\end{array}$

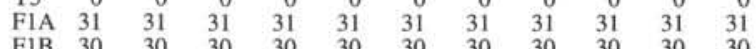
$\begin{array}{llllllllllll}\mathrm{F} 1 \mathrm{~B} & 30 & 30 & 30 & 30 & 30 & 30 & 30 & 30 & 30 & 30 & 30 \\ \mathrm{~F} 2 & 27 & 25 & 24 & 21 & 19 & 17 & 16 & 15 & 14 & 13 & 12\end{array}$

Sept $\begin{array}{llllllllllll}\mathrm{Y} 1 & 0 & 0 & 0 & 0 & 0 & 0 & 0 & 0 & 0 & 0 & 0 \\ \mathrm{Y} 2 & 8 & 7 & 7 & 6 & 5 & 4 & 3 & 2 & 1 & 0 & 0\end{array}$ $\begin{array}{llllllllllll}\mathrm{Y} 3 & 0 & 0 & 0 & 0 & 5 & 4 & 3 & 2 & 1 & 0 & 0 \\ \mathrm{Y} 4 & 7 & 6 & 5 & 4 & 3 & 0 & 0 & 0 & 0 & 0 & 0\end{array}$ $\begin{array}{llllllllllll}\text { Y4 } & 7 & 6 & 5 & 4 & 3 & 2 & 1 & 0 & 0 & 0 & 0 \\ \text { Y5 } & 0 & 0 & 0 & 0 & 0 & 0 & 0 & 0 & 0 & 0 & 0\end{array}$ $\begin{array}{llllllllllll}\text { F1A } & 30 & 30 & 30 & 30 & 30 & 30 & 30 & 30 & 29 & 28 & 27 \\ \text { F1B } & 30 & 30 & 30 & 30 & 30 & 30 & 30 & 30 & 30 & 30 & 29\end{array}$ $\begin{array}{llllllllllll}\text { F1B } & 30 & 30 & 30 & 30 & 30 & 30 & 30 & 30 & 30 & 30 & 29 \\ \text { F2 } & 30 & 30 & 30 & 30 & 30 & 30 & 30 & 30 & 29 & 28 & 27\end{array}$

1974

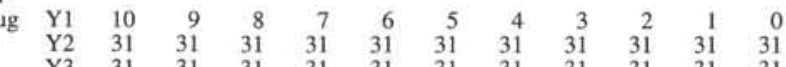

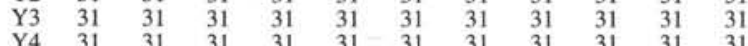

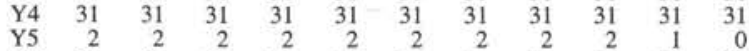

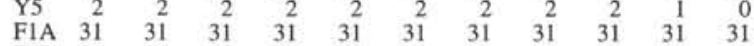

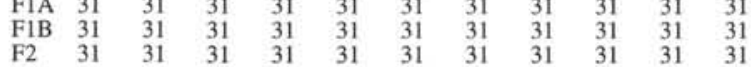

$\begin{array}{rrrrrrrrrrrrr}\text { Sept } & \mathrm{Y} 1 & 9 & 7 & 6 & 5 & 4 & 3 & 2 & 1 & 0 & 0 & 0 \\ & \mathrm{Y} 2 & 30 & 30 & 30 & 30 & 30 & 30 & 30 & 30 & 30 & 30 & 30\end{array}$ $\begin{array}{rrrrrrrrrrrr}\mathrm{Y} 2 & 30 & 30 & 30 & 30 & 30 & 30 & 30 & 30 & 30 & 30 & 30 \\ \mathrm{Y} 3 & 19 & 17 & 16 & 15 & 14 & 13 & 12 & 11 & 10 & 8 & 7 \\ \mathrm{Y} 4 & 19 & 17 & 16 & 15 & 14 & 13 & 12 & 11 & 10 & 8 & 7\end{array}$ $\begin{array}{rrrrrrrrrrrr}\text { Y5 } & 13 & 10 & 8 & 5 & 4 & 3 & 2 & 1 & 0 & 0 & 0 \\ \text { F1A } & 30 & 30 & 30 & 30 & 30 & 30 & 30 & 30 & 30 & 30 & 30\end{array}$

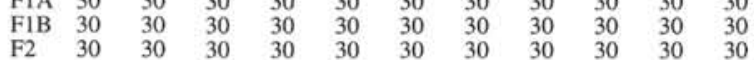

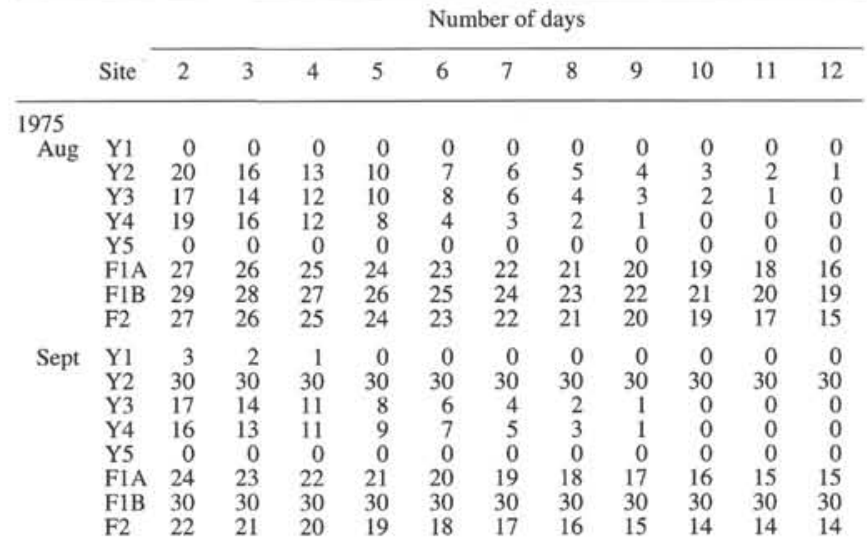

1976

$\begin{array}{lllllllllllll}\text { Aug } & \mathrm{Y} 1 & 20 & 19 & 18 & 17 & 16 & 15 & 14 & 13 & 12 & 11 & 10\end{array}$

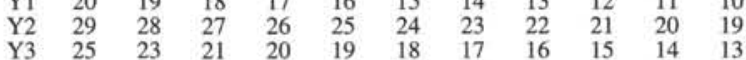
$\begin{array}{llllllllllll}\mathrm{Y} 3 & 25 & 23 & 21 & 20 & 19 & 18 & 17 & 16 & 15 & 14 & 13 \\ \mathrm{Y} 4 & 25 & 24 & 21 & 20 & 19 & 18 & 17 & 16 & 15 & 14 & 13\end{array}$

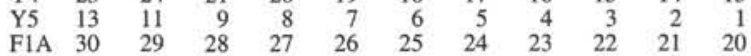

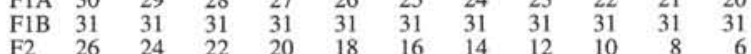

$\begin{array}{lllllllllllll}\text { Sept } & \mathrm{Y} 1 & 0 & 0 & 0 & 0 & 0 & 0 & 0 & 0 & 0 & 0 & 0\end{array}$

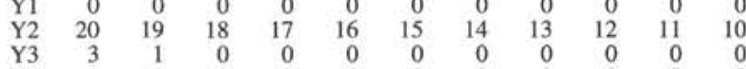
$\begin{array}{llllllllllll}\text { Y4 } & 1 & 0 & 0 & 0 & 0 & 0 & 0 & 0 & 0 & 0 & 0 \\ \text { Y5 } & 0 & 0 & 0 & 0 & 0 & 0 & 0 & 0 & 0 & 0 & 0\end{array}$ $\begin{array}{rrrrrrrrrrrr}\text { Y5 } & 0 & 0 & 0 & 0 & 0 & 0 & 0 & 0 & 0 & 0 & 0 \\ \text { F1A } & 15 & 14 & 13 & 12 & 11 & 9 & 7 & 6 & 5 & 4 & 3 \\ \text { FIB } & 22 & 21 & 20 & 19 & 18 & 17 & 16 & 15 & 14 & 13 & 12\end{array}$ $\begin{array}{lrrrrrrrrrrr}\text { F1B } & 22 & 21 & 20 & 19 & 18 & 17 & 16 & 15 & 14 & 13 & 12 \\ \text { F2 } & 13 & 12 & 11 & 10 & 9 & 8 & 7 & 6 & 5 & 4 & 3\end{array}$ 1977

Aug $\begin{array}{lrrrrrrrrrrr}\text { Y1 } & 0 & 0 & 0 & 0 & 0 & 0 & 0 & 0 & 0 & 0 & 0 \\ \text { Y2 } & 8 & 6 & 4 & 2 & 1 & 0 & 0 & 0 & 0 & 0 & 0 \\ \text { Y3 } & 4 & 3 & 2 & 1 & 0 & 0 & 0 & 0 & 0 & 0 & 0 \\ \text { Y4 } & 0 & 0 & 0 & 0 & 0 & 0 & 0 & 0 & 0 & 0 & 0 \\ \text { Y5 } & 0 & 0 & 0 & 0 & 0 & 0 & 0 & 0 & 0 & 0 & 0 \\ \text { F1A } & 31 & 31 & 31 & 31 & 31 & 31 & 31 & 31 & 31 & 31 & 31 \\ \text { F1B } & 31 & 31 & 31 & 31 & 31 & 31 & 31 & 31 & 31 & 31 & 31 \\ \text { F2 } & 31 & 31 & 31 & 31 & 31 & 31 & 31 & 31 & 31 & 31 & 31\end{array}$ $\begin{array}{lllllllllllll}\text { Sept } & \mathrm{Y} 1 & 0 & 0 & 0 & 0 & 0 & 0 & 0 & 0 & 0 & 0 & 0\end{array}$ $\begin{array}{llllllllllll}\mathrm{Y} 2 & 8 & 6 & 4 & 2 & 1 & 0 & 0 & 0 & 0 & 0 & 0 \\ \mathrm{Y} 3 & 4 & 3 & 2 & 1 & 0 & 0 & 0 & 0 & 0 & 0 & 0 \\ \mathrm{Y} 4 & 0 & 0 & 0 & 0 & 0 & 0 & 0 & 0 & 0 & 0 & 0\end{array}$ $\begin{array}{lrrrrrrrrrrr}\text { Y5 } & 0 & 0 & 0 & 0 & 0 & 0 & 0 & 0 & 0 & 0 & 0 \\ \text { F1A } & 30 & 30 & 30 & 30 & 30 & 30 & 30 & 30 & 30 & 30 & 30\end{array}$

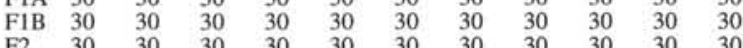
1978

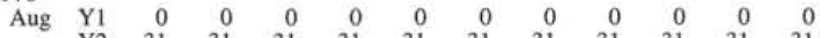
$\begin{array}{llllllllllll}\text { Y2 } & 31 & 31 & 31 & 31 & 31 & 31 & 31 & 31 & 31 & 31 & 31 \\ \text { Y3 } & 24 & 23 & 22 & 21 & 20 & 19 & 18 & 17 & 16 & 15 & 14\end{array}$ $\begin{array}{rrrrrrrrrrrr}\mathrm{Y} 4 & 24 & 23 & 22 & 21 & 20 & 19 & 18 & 17 & 16 & 15 & 14 \\ \mathrm{Y} 5 & 0 & 0 & 0 & 0 & 0 & 0 & 0 & 0 & 0 & 0 & 0\end{array}$

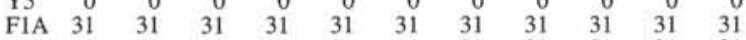

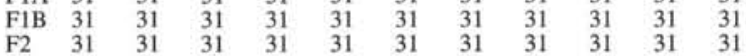
$\begin{array}{rrrrrrrrrrrrr}\text { Sept } & \mathrm{Y} 1 & 0 & 0 & 0 & 0 & 0 & 0 & 0 & 0 & 0 & 0 & 0 \\ & \mathrm{Y} 2 & 28 & 27 & 26 & 24 & 22 & 20 & 18 & 17 & 16 & 15 & 14\end{array}$ $\begin{array}{rrrrrrrrrrrr}\mathrm{Y} 2 & 28 & 27 & 26 & 24 & 22 & 20 & 18 & 17 & 16 & 15 & 14 \\ \mathrm{Y} 3 & 12 & 10 & 9 & 8 & 7 & 6 & 5 & 4 & 3 & 2 & 1\end{array}$ $\begin{array}{rrrrrrrrrrrr}\mathrm{Y} 4 & 15 & 14 & 13 & 12 & 11 & 10 & 9 & 8 & 7 & 6 & 5 \\ \mathrm{Y} 5 & 0 & 0 & 0 & 0 & 0 & 0 & 0 & 0 & 0 & 0 & 0\end{array}$ $\begin{array}{llllllllllll}\text { FIA } & 30 & 30 & 30 & 30 & 30 & 30 & 30 & 30 & 30 & 30 & 30 \\ \text { FIB } & 30 & 30 & 30 & 30 & 30 & 30 & 30 & 30 & 30 & 30 & 30\end{array}$ $\begin{array}{llllllllllll}\mathrm{F} 2 & 30 & 30 & 30 & 30 & 30 & 30 & 30 & 30 & 30 & 30 & 30\end{array}$ 1979

Aug $\begin{array}{rrrrrrrrrrrr}\mathrm{Y} 1 & 0 & 0 & 0 & 0 & 0 & 0 & 0 & 0 & 0 & 0 & 0 \\ \mathrm{Y} 2 & 31 & 31 & 31 & 31 & 31 & 31 & 31 & 31 & 31 & 31 & 31\end{array}$ $\begin{array}{llllllllllll}\text { Y2 } & 31 & 31 & 31 & 31 & 31 & 31 & 31 & 31 & 31 & 31 & 31 \\ \text { Y3 } & 29 & 28 & 27 & 26 & 25 & 24 & 23 & 22 & 21 & 21 & 21 \\ \text { Y4 } & 29 & 28 & 27 & 26 & 25 & 24 & 23 & 22 & 21 & 21 & 21\end{array}$ $\begin{array}{rrrrrrrrrrrr}\text { Y4 } & 29 & 28 & 27 & 26 & 25 & 24 & 23 & 22 & 21 & 21 & 21 \\ \text { Y5 } & 8 & 7 & 6 & 5 & 4 & 3 & 2 & 1 & 0 & 0 & 0\end{array}$

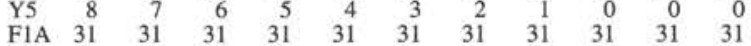
$\begin{array}{llllllllllll}\text { F1A } & 31 & 31 & 31 & 31 & 31 & 31 & 31 & 31 & 31 & 31 & 31 \\ \text { F1B } & 31 & 31 & 31 & 31 & 31 & 31 & 31 & 31 & 31 & 31 & 31 \\ \text { F2 } & 31 & 31 & 31 & 31 & 31 & 31 & 31 & 31 & 31 & 31 & 31\end{array}$ $\begin{array}{lllllllllllll}\text { Sept } & \mathrm{Y} 1 & 23 & 23 & 23 & 23 & 23 & 23 & 23 & 23 & 23 & 23 & 23 \\ \mathrm{Y} 2 & 30 & 30 & 30 & 30 & 30 & 30 & 30 & 30 & 30 & 30 & 30\end{array}$

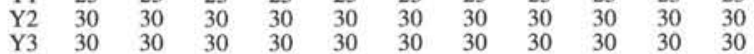
$\begin{array}{llllllllllll}\mathrm{Y} 4 & 30 & 30 & 30 & 30 & 30 & 30 & 30 & 30 & 30 & 30 & 30 \\ \mathrm{Y} 5 & 18 & 15 & 13 & 12 & 12 & 12 & 12 & 12 & 12 & 12 & 12\end{array}$

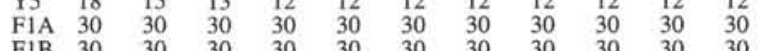
$\begin{array}{llllllllllll}\mathrm{F} 2 & 30 & 30 & 30 & 30 & 30 & 30 & 30 & 30 & 30 & 30 & 30\end{array}$ 
to be ice free in August than in September. Only Site Y1 has its peak tendency in September (10th). Our conclusion is that, for most sites, to achieve the optimum probability of ice-free success with a 4-day window, it is best to work during the second half of August.

\section{SITE-BY-SITE REVIEW}

We draw the following conclusions about the suitability of the eight individual sites. There are four levels of difficulty for drilling, which can be summarized as follows:

\begin{tabular}{ll}
\hline Very favorable sites & F1B \\
& F1A \\
& F2 \\
Favorable site & Y2 \\
Unfavorable sites & Y4 \\
& Y3 \\
Very unfavorable sites & Y1 \\
& Y5
\end{tabular}

\section{Very Unfavorable Sites}

Y1 is the northernmost site, beyond $81^{\circ} \mathrm{N}$ (Fig. 1; Table 1), and lies to the north of the typical limit of so-called "Whaler's Bay" (Vinje, 1977), the ice-free bight kept open by the warm water of the West Spitsbergen Current. This implies that at most times of most years it is covered by heavy polar pack ice, but that in exceptional years, when the polar front is displaced northward by wind or current forcing, it may become uncovered. Under these circumstances it will tend to remain ice free for lengthy periods, and so it tends to be either completely ice covered through the July-October period or else (more rarely) relatively ice free throughout the period (Table 3 ). July conditions can, therefore, be useful as a guide to August and September.

An approach to Site Y1 has only a $3.6 \%$ probability of encountering ice-free conditions in July, rising to $11.1 \%$ in August, a peak of $14.8 \%$ in September, and a drop to $3.9 \%$ in October (Table 4). Thus, during high summer the site is ice free only 1 day in $7-9$, and the month-to-month persistence demonstrated in Table 3 shows that if it is ice-covered in July it is likely to remain completely ice-covered throughout the summer. Table 6 shows that, for the $1970-1979$ period (more favorable than the 1966-1990 period as a whole), there was a $16.5 \%$ chance of encountering open water that would remain open for a further day (dropping to $10.0 \%$ for 12 successive days) in August and a $21.7 \%$ chance ( $14.7 \%$ for 12 days) in September. Table 7 shows that if a ship sails to the region and is prepared to wait, there is still only a 3 in 10 chance of encountering 2 days of open water at any time in August ( 2 in 10 for 12 days), 4 in 10 in September, and 5 in 10 if the ship can wait the whole 2 months. Our conclusion was that this site should only be contemplated in August or September if satellite images should show it to be open in July.

Y5 lies to the south of Y1, Y3, and Y4 (Fig. 1), but its westerly position places it firmly within the influence of the main Transpolar Drift Stream, transporting heavy polar pack ice. Only rarely does the ice edge shift far enough to the west to uncover this site. The occurrence of ice-free conditions is highly irregular and varies greatly from year to year. What tends to occur (Table 3) is that in most years the site is completely ice-covered for the whole of the 4-month summer period, with at most a day or two of open water (1966-1970, 1973, $1975,1981,1987$, and 1991), while in other years the bodily shift of the ice edge creates a reasonable quantity of ice-free days throughout the summer $(1972,1974,1979,1982,1983,1985$, and 1990).

For a ship approaching the site at random, there is a $21 \%$ chance of finding it ice free in September and a 13\% chance in August (8\% in July and $13 \%$ in October; Table 4). For 1970-1979, there is a $17 \%$ chance of encountering a 2-day ice-free window at random in September (dropping to only $5 \%$ for 12 days), and a $12 \%$ chance for 2 days in August (dropping to a mere 1\% for 12 days; Table 6). For a ship prepared to wait, a 2 -day ice-free window occurs some time in August in 5 years out of 10 , and in 3 years out of 10 in September ( 2 years out of 10 for a 12-day window). Site Y5 is, therefore, unfavorable; even when ice-free conditions prevail, the ice edge is never far away and is composed of very heavy ice, including many multiyear floes (Wadhams, 1983).

\section{Unfavorable Sites}

Y3 lies north of the average limit of Whaler's Bay. Because of its southeasterly location, however, the ice that it experiences tends to be younger (mainly first-year) ice, which originates north of Russia and which moves westward across the north of Svalbard to join the ice streams entering the Fram Strait (Wadhams [1983, 1989, 1992] has analyzed ice thicknesses and types in this region). For this location, as for Y1, July conditions can often be used as a predictor of late summer conditions, especially of heavy ice seasons (Table 3). In 1966$1969,1973,1987$, and 1991, a complete absence of ice-free days in July presaged their continued absence through October. On the other hand, there have also been years in which the ice edge has moved past Y3 so as to give 1, or 2, months of ice-free conditions that could not be predicted (e.g., 1971, 1975, 1976, 1980, 1982, and 1986).

A ship approaching $\mathrm{Y} 3$ on a random day in high summer has a less than even chance of encountering ice-free conditions (44\% in August and $37 \%$ in September), which diminishes rapidly in July (22\%) and October (30\%; Table 4). For 1970-1979, the probability of randomly encountering a 2-day ice-free period in August is 56\% (Table 6), dropping to $36 \%$ for 12 days, whereas in September it is $38 \%$, dropping to $20 \%$. For a ship prepared to wait, there is a 9 in 10 chance of encountering at least one 2-day ice-free period in August (6 in 10 for 12 days), and a 7 in 10 chance in September ( 4 in 10 for 12 days) (Table 7). Thus, we can consider $\mathrm{Y} 3$ a marginal case that may be considered for drilling during an indisputably good ice year.

Y4 is close to Y3 and shares its statistical attributes. Once again, heavy ice conditions in July are often followed by a summer of heavy ice (1967-1969), although less often than is the case for Y3. We find, for instance, in 1966, 1973, 1987, and 1991, that whereas Y3 experienced an icebound July followed by a totally icebound August-October, Y4 did experience some ice-free days during August-October after an equally icebound July. This is due to Y4's slightly more favorable position relative to the ice edge bight around the north of the Fram Strait. Cases of one or two months of favorable conditions, not susceptible to prediction, occur during the same years as Y3.

The probability of randomly encountering an ice-free day during summer is very slightly greater than for Y3 (46\% in August and $41 \%$ in September, dropping to $26 \%$ in July and $23 \%$ in October). For the $1970-1979$ period, the chance of randomly encountering 2 successive ice-free days is $57 \%$ ( $36 \%$ for 12 successive days) in August and $42 \%$ in September ( $21 \%$ for 12 days). For a waiting ship, a 2-day icefree period occurs some time in August in 8 years out of 10 (6 out of 10 for 12 days), and in September in 8 years out of 10 (4 out of 10 for 12 days). If the ship can wait 2 months, the chances are 10 out of 10 years for finding a 2-day ice-free period some time during August and September combined ( 6 out of 10 for 12 days).

\section{Favorable Site}

Y2 is the most favorable site of the "Y" group. It is situated (Fig.1; Table 1) in the center-north of the Fram Strait, which brings it within the warm, open-water conditions of Whaler's Bay during many summers. In bad ice years, on the other hand, it lies within the influence of the polar pack moving westward and southward in the Transpolar Drift Stream.

As Table 5 shows, the site is either almost completely ice-free through the summer, or else is largely ice-covered but still has a few 
Table 6. The percentage probability $\left(\mathrm{p}_{\mathrm{N}}\right)$ that a given site will be ice free on a randomly chosen day and on $(N-1)$ subsequent days, based on 1970-1979 data.

\begin{tabular}{lccccccccccc}
\hline Site & $N=2$ & 3 & 4 & 5 & 6 & 7 & 8 & 9 & 10 & 11 & 12 \\
\hline August & & & & & & & & & & & \\
Y1 & 16.5 & 15.8 & 15.2 & 14.5 & 13.9 & 13.2 & 12.6 & 11.9 & 11.3 & 10.6 & 10.0 \\
Y2 & 71.9 & 68.1 & 65.2 & 62.3 & 60.0 & 58.4 & 57.1 & 56.1 & 55.2 & 54.2 & 53.2 \\
Y3 & 56.1 & 52.6 & 49.7 & 47.4 & 45.2 & 43.2 & 41.3 & 39.7 & 38.1 & 36.8 & 35.5 \\
Y4 & 56.8 & 51.6 & 49.7 & 46.8 & 43.9 & 42.3 & 40.6 & 39.0 & 37.4 & 36.5 & 35.5 \\
Y5 & 11.9 & 10.3 & 8.7 & 7.7 & 6.8 & 5.8 & 4.8 & 3.9 & 2.9 & 1.9 & 1.0 \\
F1A & 96.8 & 95.8 & 94.8 & 93.9 & 92.9 & 92.0 & 91.3 & 90.6 & 90.0 & 89.0 & 87.7 \\
F1B & 99.0 & 98.7 & 98.4 & 98.1 & 97.7 & 97.4 & 97.1 & 96.8 & 96.5 & 95.8 & 95.2 \\
F2 & 94.2 & 92.3 & 90.3 & 88.4 & 86.5 & 84.5 & 82.9 & 81.3 & 79.7 & 77.7 & 75.8 \\
September & & & & & & & & & & & \\
Y1 & 21.7 & 20.7 & 19.7 & 18.7 & 18.0 & 17.3 & 16.7 & 16.0 & 15.3 & 15.0 & 14.7 \\
Y2 & 73.7 & 71.3 & 69.3 & 67.0 & 64.3 & 62.0 & 59.7 & 57.7 & 55.7 & 54.0 & 52.7 \\
Y3 & 37.7 & 34.0 & 31.7 & 29.7 & 28.0 & 26.3 & 24.7 & 23.3 & 22.0 & 20.7 & 19.7 \\
Y4 & 42.0 & 38.3 & 35.7 & 33.3 & 31.0 & 28.7 & 26.3 & 24.3 & 23.0 & 21.7 & 20.7 \\
Y5 & 16.7 & 14.0 & 12.0 & 10.0 & 9.0 & 8.0 & 7.0 & 6.3 & 5.7 & 5.3 & 5.0 \\
F1A & 86.0 & 85.0 & 84.0 & 83.0 & 82.0 & 80.7 & 79.3 & 78.3 & 77.3 & 76.7 & 76.3 \\
F1B & 90.3 & 89.7 & 89.0 & 88.3 & 87.7 & 87.0 & 86.3 & 85.7 & 85.0 & 84.7 & 84.0 \\
F2 & 82.0 & 80.7 & 79.3 & 78.0 & 76.7 & 75.3 & 74.3 & 73.3 & 72.0 & 71.0 & 70.0 \\
\hline
\end{tabular}

days of ice-free conditions. It is seldom completely ice-covered right through the summer as is Y1. A ship approaching the site during August or September has a $72 \%$ chance of encountering open water (62\% in July or October; Table 4). From Table 6 we see that for persistent open-water conditions, August and September are also very similar: there is a $72 \%$ chance in August of encountering open water that persists for a second day and a $53 \%$ chance of encountering open water that persists for 12 days ( $74 \%$ and $53 \%$ in September). If a ship can afford to wait for a favorable opportunity, Table 7 shows that in every year during the 1970 s there was at least one occasion during both August and September when 3 successive ice-free days could be found, and there were high probabilities of finding up to 12 successive ice-free days at some time during a month ( 7 in 10 years).

\section{Very Favorable Sites}

F1A, like all the FRAM sites, is an area where ice-free conditions prevail much of the time. Even when the area is ice-covered, it will usually become uncovered after a reasonable wait. During July-October there are plentiful ice-free days in every year (Table 3). In the late 1960 s, it sometimes happened that the site would be completely or almost completely ice-covered for a month at a time (September 1967 ; July and October 1968), but by the early 1970 s milder ice conditions took over, and from 1977 onward the site has been almost permanently ice free during summer. This clearly corresponds to a real climatic shift in the nature of the East Greenland ice, which is the chief cause of the change in total coverage of the eight sites, which is shown in Figure 3. During the late 1960s, an exceptionally unfavorable period of ice conditions in East Greenland occurred. At lower latitudes, it showed itself in a renewed tendency for ice to engulf the coasts of Iceland in winter, a problem that led to the calling of an International Sea Ice Conference in Reykjavik in 1971 (Karlsson, 1972). In the Fram Strait, as the data in this paper demonstrate, it showed itself by a tendency for the ice edge in the Fram Strait at $78^{\circ}-$ $79^{\circ} \mathrm{N}$ to lie farther to the east (suggesting a greater ice flux out of the Arctic Basin through the Fram Strait), but without a significant accompanying effect on the location of the ice edge to the north of the Fram Strait in Whaler's Bay. Thus, the FRAM sites had bad ice conditions in the late 1960 s. By the beginning of the 1970 s, these conditions changed and have remained more favorable; Iceland is seldom menaced by winter ice, and the ice edge in the Fram Strait lies farther to the west. If present conditions continue, the FRAM sites will remain likely to be ice free and, thus, suitable for drilling. A scrutiny of seawater temperatures showed that ice-free conditions also frequently correspond to surface water temperatures warmer than $4^{\circ} \mathrm{C}$, indicating that the site is lying to the east of the polar front and so is not
Table 7. Number of years during the period from 1970 to 1979 when icefree conditions occurred at least once for $N$ days.

\begin{tabular}{lrrrrrrrrrrr}
\hline \multicolumn{1}{c}{ Site } & $N=2$ & 3 & 4 & 5 & 6 & 7 & 8 & 9 & 10 & 11 & 12 \\
\hline August & & & & & & & & & & & \\
Y1 & 3 & 3 & 3 & 3 & 3 & 3 & 3 & 3 & 3 & 3 & 2 \\
Y2 & 10 & 10 & 9 & 9 & 9 & 8 & 8 & 8 & 7 & 7 & 7 \\
Y3 & 9 & 9 & 8 & 8 & 7 & 7 & 7 & 7 & 7 & 7 & 6 \\
Y4 & 8 & 8 & 7 & 7 & 7 & 7 & 7 & 7 & 7 & 6 & 6 \\
Y5 & 5 & 5 & 4 & 4 & 4 & 4 & 4 & 4 & 3 & 3 & 2 \\
F1A & 10 & 10 & 10 & 10 & 10 & 10 & 10 & 10 & 10 & 10 & 10 \\
F1B & 10 & 10 & 10 & 10 & 10 & 10 & 10 & 10 & 10 & 10 & 10 \\
F2 & 10 & 10 & 10 & 10 & 10 & 10 & 10 & 10 & 10 & 10 & 10 \\
September & & & & & & & & & & & \\
Y1 & 4 & 4 & 4 & 3 & 3 & 3 & 3 & 3 & 2 & 2 & 2 \\
Y2 & 10 & 10 & 10 & 10 & 9 & 9 & 9 & 9 & 8 & 7 & 7 \\
Y3 & 7 & 6 & 5 & 5 & 5 & 5 & 5 & 5 & 4 & 4 & 4 \\
Y4 & 8 & 7 & 7 & 7 & 7 & 7 & 6 & 5 & 4 & 4 & 4 \\
Y5 & 3 & 3 & 3 & 3 & 3 & 3 & 3 & 3 & 2 & 2 & 2 \\
F1A & 10 & 10 & 10 & 10 & 10 & 10 & 10 & 10 & 10 & 10 & 10 \\
F1B & 10 & 10 & 10 & 10 & 10 & 10 & 10 & 10 & 10 & 10 & 10 \\
F2 & 10 & 10 & 10 & 10 & 10 & 9 & 9 & 9 & 9 & 9 & 9 \\
August and & & & & & & & & & & & \\
September & & & & & & & & & & & \\
Y1 & 5 & 5 & 5 & 4 & 4 & 4 & 4 & 4 & 4 & 4 & 3 \\
Y2 & 10 & 10 & 10 & 10 & 10 & 10 & 10 & 10 & 9 & 8 & 8 \\
Y3 & 9 & 9 & 8 & 8 & 7 & 7 & 7 & 7 & 7 & 7 & 6 \\
Y4 & 10 & 10 & 9 & 9 & 9 & 9 & 8 & 7 & 6 & 6 & 6 \\
F1A & 10 & 10 & 10 & 10 & 10 & 10 & 10 & 10 & 10 & 10 & 10 \\
F1B & 10 & 10 & 10 & 10 & 10 & 10 & 10 & 10 & 10 & 10 & 10 \\
F2 & 10 & 10 & 10 & 10 & 10 & 10 & 10 & 10 & 10 & 10 & 10 \\
\hline
\end{tabular}

subject to incursions by stray streamers of wind-driven ice. This is also true of Site F1B.

A random approach to the site will find it ice free $91 \%$ of the time in August and $84 \%$ in September (Table 4). Even in July it is ice free $82 \%$ of the time ( $86 \%$ in October), so operations outside of the high summer window can be planned with some confidence. During $1970-1979$, there was a $97 \%$ probability of finding a 2-day ice-free window during a random approach in August ( $88 \%$ for 12 days), and an $86 \%$ probability in September ( $76 \%$ for 12 days). In 10 out of those 10 years, a window of 12 ice-free days could be found at some time in August or September.

F1B is even more favorable than F1A because it lies farther to the east. As well as being ice free, it, therefore, tends to be located in a warm water zone, which increases the margin of safety from sudden wind-driven ice forays. During August the site is ice free $96 \%$ of the time (92\% in September). Again, early and late season drilling are possible since it is ice free $94 \%$ of the time in July and 91\% in October. During 1970-1979, a 2-day ice-free window was encountered during a random approach on $99 \%$ of occasions (95\% for a 12 -day 


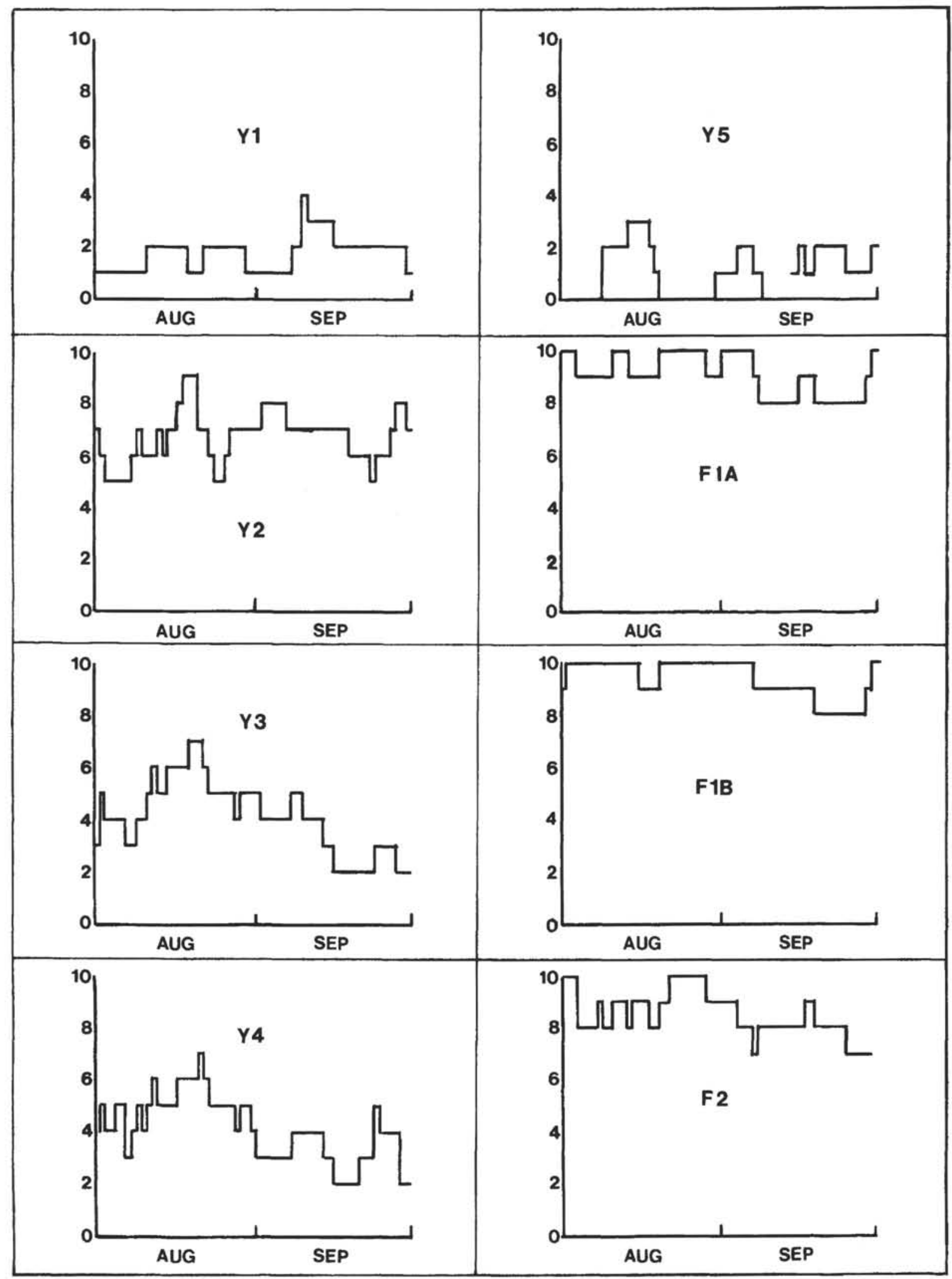

Figure 4. Number of years during 1970-1979 when, on a given date during August-September, a given site is ice free and remains ice free for the subsequent 3 days (a total of 4 ice-free days). 
window) in August and $90 \%$ of occasions in September ( $84 \%$ for a 12-day window). Again, in the unlikely event that a ship has to wait for ice-free conditions, it would find them in 10 out of 10 years at some point during August or September, for a 12-day drilling window.

F2 is the most westerly of the three FRAM sites, and is, thus, the least favorable of the three, although the differences from F1A and F2 are marginal. Its statistical attributes resemble F1A very closely (Table 3), especially regarding the transition from the late 1960s to the $1970-1991$ ice regime. It is ice free $90 \%$ of the time in August and $81 \%$ in September, although July and October figures (77\% and $80 \%$ ) are slightly lower than for F1 A and F1B and so make it slightly less favorable for early and late season drilling. During 1970-1979, a random approach to the site would encounter a 2-day ice-free window on $94 \%$ of occasions in August (76\% for a 12-day window) and on $82 \%$ of occasions in September ( $70 \%$ for a 12-day window). In 10 out of 10 years, a 12-day window could be found at some point during August for a ship prepared to wait, whereas in September a window up to 6 days long could be found in 10 out of 10 years and a 12-day window in 9 out of 10 years.

Since this site is slightly less favorable than F1A and F1B, we recommended that it should be drilled first if it is found to be ice free, because there is greater confidence that F1A and F1B will not experience ice problems at any time.

\section{SUMMARY OF ICE CONDITIONS ACTUALLY EXPERIENCED}

Leg 151 of the Ocean Drilling Program (North Atlantic-Arctic Gateways I) was carried out from 24 July to 24 September 1993 (Myhre et al., 1993; Shipboard Scientific Party, 1994). Seven sites were drilled. Sites 907 and 913 were far south in the Greenland Sea. The remaining sites, and ice conditions encountered, are listed in Table 8 .

Site YERM5 could not be approached because of heavy ice. Site YERM1 was also within heavy pack, but a site $10 \mathrm{nmi}$ to the south of it (designated YERM1D) was approached and was 6-7 nmi outside the ice edge. Drilling was possible but was not done for technical reasons unconnected with the ice.

Our statistical findings were correct in describing FRAM2 and FRAM1A as very favorable, and YERM1 and YERM5 as very unfavorable. We listed YERM4 and YERM3 as "unfavorable," but drilling did proceed although ice came within $3.65 \mathrm{nmi}$ of YERM4. We had listed YERM2 as "favorable." Between the times of our analysis and of the cruise, however, this site was moved $19 \mathrm{nmi}$ due north, and thus Site 912 , which was severely affected by ice, was not subject to statistical analysis.

\section{CONCLUSIONS}

The ice conditions experienced by the drilling ship corresponded well with the predictions of this analysis, although the conditions were somewhat milder in that two "unfavorable" sites could be drilled. The analysis was carried out in time to be of use in ODP planning for Leg 151 and demonstrates the value of the standard sea-ice
Table 8. Ice conditions encountered at Leg 151 sites in Fram Strait area.

\begin{tabular}{|c|c|c|}
\hline Site & Original designation & Ice conditions \\
\hline 908 & FRAM2 & No ice nearby \\
\hline 909 & FRAMIA & Nearest ice $17 \mathrm{nmi} \mathrm{W}$ \\
\hline 910 & YERM4 & Ice $3.65 \mathrm{nmi}$ away \\
\hline 911 & YERM3 & No ice nearby \\
\hline 912 & $19 \mathrm{nmi} \mathrm{N}$ of YERM2 & $\begin{array}{l}\text { Halted due to encroaching ice; several short cores } \\
\text { obtained }\end{array}$ \\
\hline
\end{tabular}

charts produced by national meteorological offices. They are a unique source of ready-processed ice data presented in a form that is suitable for statistical analysis for a variety of ice climatology purposes. A further example of such a statistical approach was an analysis of summer ice conditions along the north coast of Alaska for the period 1953-1975 carried out by Cox and Dehn (1981).

It should be noted that ice edge information from national meteorological offices is now becoming available in digitized form (e.g., at Norsk Polarinstitutt, T. Vinje, pers. comm.), which will make future statistical analyses of this kind easier.

\section{ACKNOWLEDGMENTS}

We are grateful to the Ocean Drilling Program for support for this analysis; to Mr. Michael Wood, Archivist at the Meteorological Office, Bracknell, for providing access to the original ice charts and for his helpfulness; and to Capt. Austin Maytham, Meteorological Office, for organizing the production of the charts used.

\section{REFERENCES}

Cox, G.F.N., and Dehn, W.S., 1981. Summer ice conditions in the Prudhoe Bay area, 1953-75. In Michel, B. (Ed.), Proc. 6th Int. Conf. on Port and Ocean Eng. Under Arctic Conditions (POAC-81), Quebec City, 27-31 July $1981,799-808$.

Karlsson, T. (Ed.), 1972. Sea Ice: Reykjavik (Nat. Res. Counc. of Iceland).

Myhre, A.M., Thiede, J., and Firth, J.V., 1993. Leg 151 Preliminary Report: North Atlantic Arctic Gateways 1: College Station, TX (Ocean Drilling Program).

Shipboard Scientific Party [ODP Leg 151], 1994. Exploring Arctic history through scientific drilling. Eos, 75:281-286.

Vinje, T.E., 1977. Sea ice conditions in the European sector of the marginal seas of the Arctic, 1966-75. Nor. Polarinst. Arbok, 1975:163-174.

Wadhams, P., 1981. The ice cover in the Greenland and Norwegian Seas. Rev. Geophys. Space Phys., 19:345-393.

, 1983. Sea ice thickness distribution in Fram Strait. Nature, 305:108-111.

, 1986. The ice cover. In Hurdle, B.G. (Ed.), The Nordic Seas: New York (Springer-Verlag).

- 1989. Sea-ice thickness distribution in the Transpolar Drift Stream. Rapp. P.-V. Reun. Cons. Int. Explor. Mer, 188:59-65.

, 1992. Sea-ice thickness distribution in the Greenland Sea and Eurasian Basin, May 1987. J. Geophys. Res., 97:5331-5348.

Date of initial receipt: 30 June 1995

Date of acceptance: 3 December 1995

Ms 151SR-151 